\title{
The origins of pottery in East Asia: updated analysis (the 2015 state-of-the-art)
}

\author{
Yaroslav V. Kuzmin \\ Institute of Geology and Mineralogy, Siberian Branch of the Russian Academy of Sciences, Novosibirsk/ \\ Laboratory of Mesozoic and Cenozoic Continental Ecosystems, Tomsk State University, Tomsk, RU \\ kuzmin@fulbrightmail.org
}

\begin{abstract}
Recent developments related to the emergence of pottery in East Asia and neighbouring regions are presented. According to a critical evaluation of the existing evidence, the oldest centres with pottery in East Asia are situated in South China (dated to c. 18000 calBP), the Japanese Islands (c. 16700 calBP), and the Russian Far East (c. 15900 calBP). It is most likely that pottery-making appeared in these regions independently of each other. In Siberia, the earliest pottery now known is from the Transbaikal region (dated to c. 14000 calBP). However, it did not influence the more westerly parts of Siberia in terms of the origin and spread of pottery-making.
\end{abstract}

IZVLEČEK - Predstavljamo najnovejši razvoj študij pojava lončarstva v Vzhodni Aziji in sosedstvu. S pomočjo kritične presoje podatkov lahko sklepamo, da so najstarejši centri z lončenino $v$ Vzhodni Aziji umeščeni v južno Kitajsko (ok. 18000 calBP), Japonsko otočje (ok. 16700 calBP) in Daljni Vzhod Rusije (ok. 15900 calBP). Zelo verjetno se je izdelava lončenine $v$ teh regijah pojavila neodvisno druga od druge. V Sibiriji je najstarejše lončarstvo poznano na področju Trans-bajkala (ok. 14000 calBP). Vendar to ni vplivalo na razvoj in širjenje lončarske tehnologije v zahodne dele Sibirije.

KEY WORDS - pottery; East Asia; China; Japan; Russian Far East; Siberia; Transbaikal; radiocarbon dating; Late Glacial

\section{Introduction}

The emergence of pottery is one of the most important phenomena in prehistory (e.g., Jordan, Zvelebil 2009; Kuzmin 2013a). Although it is now widely accepted that the oldest vessels made of fired clay appeared first in greater East Asia, encompassing modern China, Japan, and the Russian Far East (e.g., Kuzmin 2006; Boaretto et al. 2009), debates about the exact location and timing of the earliest potterymaking cultural complexes have continued ( $W u$ et al. 2012; Kuzmin 2013a; 2013b; Cohen 2013). Recent attempts to model the spread of pottery technology in the Old World using the radiocarbon $\left({ }^{14} \mathrm{C}\right)$ dates of ceramic-bearing sites and the ambiguous results obtained (see Kuzmin 2013b; 2014; Silva et al. 2014) highlight the necessity of a thorough evaluation of the existing records.

The aim of this paper is to give an updated analysis of the data on the earliest pottery from greater East
Asia and neighbouring Siberia as of mid-2015 in order to introduce new information and its critical evaluation to the international scholarly community.

\section{Material and methods}

Recent overviews on the emergence of pottery among hunter-gatherers in East Asia and the neighbouring regions are used here as background (Dikshit, Hazarika 2012; Cohen 2013; Kuzmin 2013a; Gibbs, Jordan 2013; Gibbs 2015). The newly released data on the early pottery from the Transbaikal (southern part of Eastern Siberia) (Razgildeeva et al. 2013) are incorporated into the existing dataset for this region (Kuzmin 2013a; Kuzmin, Vetrov 2007; McKenzie 2009) and interpreted. Information on the Gromatukha site in the Russian Far East, published previously by Japanese scholars (see Kani 1992; Jomon 1996a; 1996a), is discussed in the 
light of a new study conducted by Shevkomud and Yanshina (2012).

The evaluation of ${ }^{14} \mathrm{C}$ dates for the early pottery complexes is crucial for understanding the origins and spread of ceramics in the Old World, and it is provided here for all the earliest pottery complexes. The calibration of ${ }^{14} \mathrm{C}$ dates was conducted with the help of the Calib 7.0.2 computer programme (Reimer et al. 2013) at \pm 2 -sigma, and all possible intervals are combined and rounded to the next ten years (see Tab. 1).

\section{Results and discussion}

\section{China}

The results of additional stu-

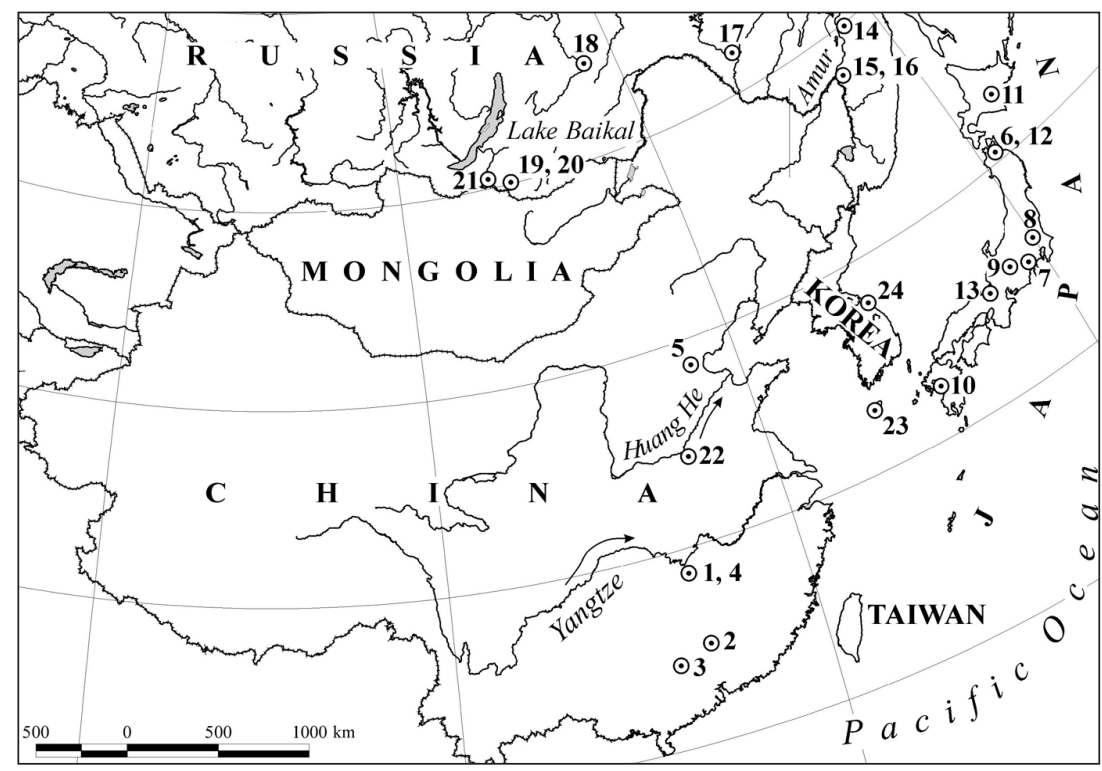

Fig. 1. Location of archaeological sites mentioned in the text. 1 Xianrendong Cave; 2 Yuchanyan Cave; 3 Miaoyan Cave; 4 Wang Dong Cave; 5 Nanzhuangtou; 6 Odai Yamamoto 1; 7 Kitahara; 8 Tokumaru Nakata; 9 Nakamachi; 10 Senpukuji Cave; 11 Taisho 3; 12 Omotedate; 13 Torihama; 14 Khummi; 15 Gasya; 16 Goncharka 1; 17 Gromatukha; 18 Ust-Karenga 12; 19 Studenoe 1; 20 Ust-Menza 1; 21 Ust-Kyakhta; 22 Lijiagou; 23 Kosanni; 24 Osanni.

dies at the Xianrendong Cave in southern China (Fig. 1) conducted in 2009 were recently published by Wu et al. (2012). According to these authors, the ${ }^{14} \mathrm{C}$ dates of the oldest site's component with pottery are $c .16915 \mathrm{BP}$ (western section) and $c .17105 \mathrm{BP}$ (eastern section), correspond to the calibrated age ranges of 19950-20 880 calBP and 20 440-20 850 calBP, respectively. If true, this would be the earliest pottery in the Old World.

However, several crucial issues allow me to cast doubt on these ${ }^{14} \mathrm{C}$ dates: (1) there is no direct association between the deer bone samples collected by
Xiaohong Wu et al. (2012) and the potsherds: "We did not recover any sherds from the reopened sections ... [in 2009]" (Wu et al. 2012.1697); (2) a ${ }^{14 C}$ date obtained previously from Stratum 3C1A, the second earliest site component with pottery - 12530 \pm 140 BP (BA95145) (MacNeish 1999.238; Kuzmin 2013a.544) - was ignored by Wu et al. (2012) despite the fact that it is much younger than the rest of the ${ }^{14} \mathrm{C}$ values from this layer at $c .13885-16340$ $\mathrm{BP}$ (Wu et al. 2012.1698); (3) some ${ }^{14} \mathrm{C}$ dates, which do not fit the age model suggested by Wu et al. (2012), were declared as 'outliers' without any reasonable explanation (see Kuzmin 2013a.544).

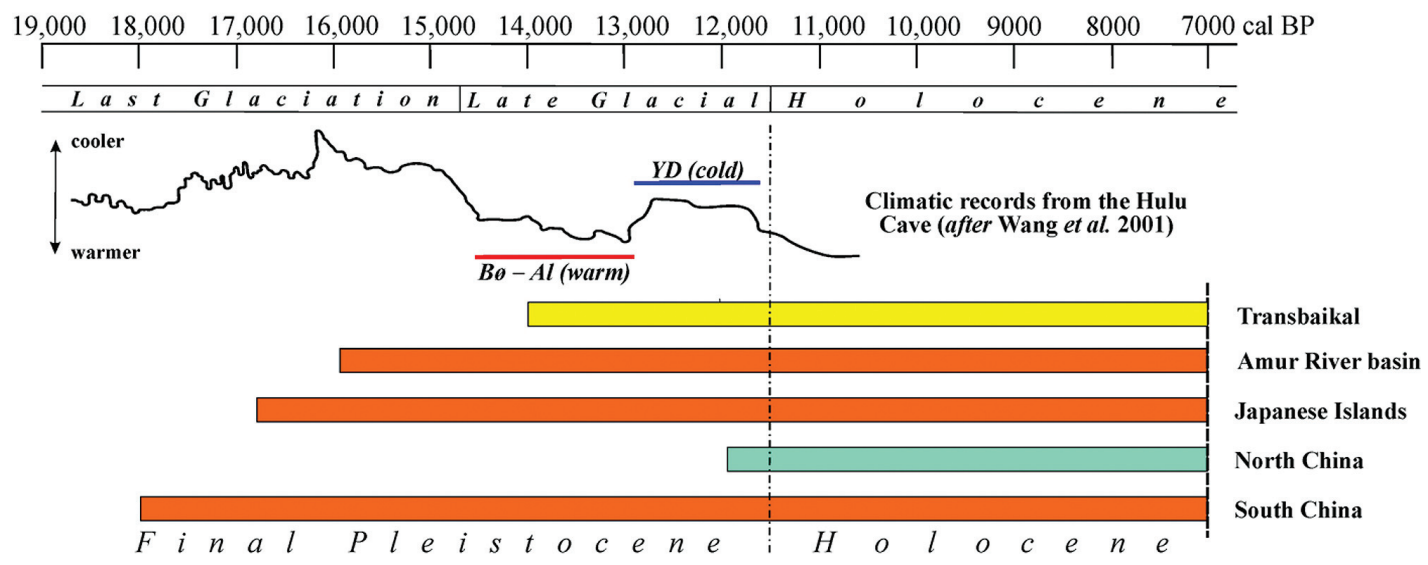

Fig. 2. Chronology of the earliest pottery complexes in greater East Asia and Siberia, on the background of climatic changes. Abbreviations: Bø-Al - Bølling-Allerød; YD - Younger Dryas. 


\begin{tabular}{|c|c|c|c|c|c|}
\hline Site & ${ }_{14} \mathrm{C}$ date, BP & Lab code and No. & $\begin{array}{c}\text { Material } \\
\text { dated }\end{array}$ & $\begin{array}{l}\text { Calendar age, } \\
\text { cal BP:*: }\end{array}$ & Reference \\
\hline \multicolumn{6}{|c|}{ South China } \\
\hline Yuchanyan Cave & $14800 \pm 55$ & RTB 5464/BAo6864 & charcoal & $17830-18190$ & Boaretto et al. 2009 \\
\hline Miaoyan Cave & $13710 \pm 270$ & BA92034-1 & charcoal & $15820-17380$ & Yuan et al. 1995 \\
\hline Xianrendong Cave & $12430 \pm 80$ & UCR-3561 & charcoal & $14160-14990$ & MacNeish 1999 \\
\hline Wang Dong Cave & $11500 \pm 150$ & BK95138A & charcoal & $13060-13700$ & MacNeish 1999 \\
\hline \multicolumn{6}{|c|}{ North China } \\
\hline Nanzhuangtou & $10210 \pm 110$ & BK-87075A & charcoal & $11400-12390$ & Yuan et al. 1992 \\
\hline \multicolumn{6}{|c|}{ Japanese Islands } \\
\hline Odai Yamamoto 1 & $13780 \pm 170$ & NUTA-6510 & adhesion & $16170-17180$ & Nakamura et al. 2001 \\
\hline Kitahara & $13060 \pm 80$ & Beta-105398 & ch. wood & $15320-15920$ & Keally et al. 2003 \\
\hline Tokumaru Nakata & $12770 \pm 225$ & PAL-383 & wood & $14240-15860$ & Keally et al. 2003 \\
\hline Nakamachi & $12740 \pm 380$ & GaK-9624 & charcoal & $13850-16180$ & Keally et al. 2003 \\
\hline Senpukuji Cave & $12220 \pm 80$ & MTC-11296 & adhesion & $13820-14520$ & Sato et al. 2011 \\
\hline Taisho 3 & $12460 \pm 40$ & Beta-194629 & adhesion & $14270-14960$ & Yamahara 2006 \\
\hline \multicolumn{6}{|c|}{ Russian Far East } \\
\hline Khummi & $13260 \pm 100$ & AA-13392 & charcoal & $15640-16240$ & Kuzmin et al. 1997 \\
\hline Gasya & $12960 \pm 120$ & LE-1781 & charcoal & $15150-15870$ & Okladnikov, Medvedev 1983 \\
\hline Goncharka 1 & $12500 \pm 60$ & LLNL-102169 & charcoal & $14300-15070$ & Shevkomud 1997 \\
\hline & $12380 \pm 70$ & MTC-05937 & charcoal & $14110-14850$ & Nesterov et al. 2006 \\
\hline Gromatukha & & Transbaikal ( & tern Siberi & & \\
\hline Ust-Karenga 12 & $12180 \pm 60$ & AA-60210 & charcoal & $13840-14240$ & Kuzmin, Vetrov 2007 \\
\hline Ust-Karenga 12 & $11240 \pm 80$ & GIN-8066 & charcoal & $12930-13280$ & Kuzmin, Vetrov 2007 \\
\hline Studenoe 1 & $11960 \pm 80$ & TKa-15554 & adhesion & $13580-14020$ & Razgildeeva et al. 2013 \\
\hline Studenoe 1 & $11995 \pm 150$ & AA-33040 & charcoal & $13470-14210$ & Buvit et al. 2003 \\
\hline Studenoe 1 & $11730 \pm 60$ & MTC-16736 & adhesion & $13450-13720$ & Razgildeeva et al. 2013 \\
\hline Ust-Menza 1 & $11550 \pm 50$ & MTC-16738 & adhesion & $13280-13470$ & Razgildeeva et al. 2013 \\
\hline \multicolumn{6}{|c|}{ * Only the oldest ${ }^{14} \mathrm{C}$ dates for each site are listed here; for more complete information, see the relevant references. } \\
\hline \multicolumn{6}{|c|}{$*$ The IntCal13 dataset (Reimer et al. 2013) is used. } \\
\hline a These dates are 1 & calculated (see $K$ & zmin 2013a). & & & \\
\hline b Only selected old & $\mathrm{t}$ sites (with ${ }^{14} \mathrm{C}$ & ates older than c. 12000 & ) are includ & see the full list in & ally et al. (2003). \\
\hline c Food remains on & ne surface of pot & ry (e.g., Nakamura et al. & 01). & & \\
\hline d Charred wood. & & & & & \\
\hline e Bulk sample colle & ed from Layer 7 . & & & & \\
\hline f Sample collected & om a hearth in L & 7. & & & \\
\hline g Sample collected & om Layer 9G. & & & & \\
\hline h Samples collecte & from Layer 8. & & & & \\
\hline
\end{tabular}

Tab. 1. The earliest East Asian and Siberian sites with pottery and their 14 C dates (from Kuzmin 2013a, with additions*).

The disturbed nature of the Xianrendong Cave profile can be easily demonstrated by information provided by Wu et al. (2012). For example, age-depth reversals are common at this site; here, there are ${ }^{14} \mathrm{C}$ dates which contradict the stratigraphic integrity' sensu David J. Cohen (2013) (layers are listed from top to bottom): (1) Layer 3B1: c. $14610 \mathrm{BP}$ (BA 093181), it is much older than the ${ }^{14} \mathrm{C}$ dates from both underlying and overlapping layers, $c$. 12 24012420 BP; (2) Layer 3B2: c. 12420 BP (UCR3561), it is much younger than the ${ }^{14} \mathrm{C}$ date from overlapping Layer 3B1 at c. $14610 \mathrm{BP}$ (see above); and (3) Layer 3C2: c. $15180 \mathrm{BP}$ (UCR3300), it is much younger than the ${ }^{14} \mathrm{C}$ dates from both underlying and over- lapping layers at $c .17580-18510 \mathrm{BP}$ and $c .16165-$ $18520 \mathrm{BP}$, respectively (see $W u$ et al. 2012.1698). As a result, the chronological model created by $\mathrm{Wu}$ et al. (2012) is heavily biased toward the older ${ }^{14} \mathrm{C}$ dates and completely ignores the possibility of postdepositional mixing of the cultural layers and material for ${ }^{14} \mathrm{C}$ dating.

Cohen (2013.62) has stated that "... these dates [by $W u$ et al. (2012)] are reliable due to the internal consistency across a large, systematic series of radiocarbon dates done on samples from stable, stratigraphic contexts ...". Being aware of criticism by Yaroslav V. Kuzmin (2013a), Cohen (2013) neverthe- 
less accepted the $c .20000-$ 20900 calBP age for the Xianrendong Cave pottery without addressing the reliability of their 'stratigraphic contexts', which are not secure due to the lack of association between bone samples for ${ }^{14} \mathrm{C}$ dating collected in 2009 and the pottery (see above). Therefore, Cohen's (2013.62-65) arguments are not convincing.

Upon critical analysis of the ${ }^{14} \mathrm{C}$ records from the earliest Chinese sites with pottery $(e$. g., Kuzmin 2006; 2013a), it is secure to conclude that the Yuchanyan Cave with ceramics dated to 17 830-18 190

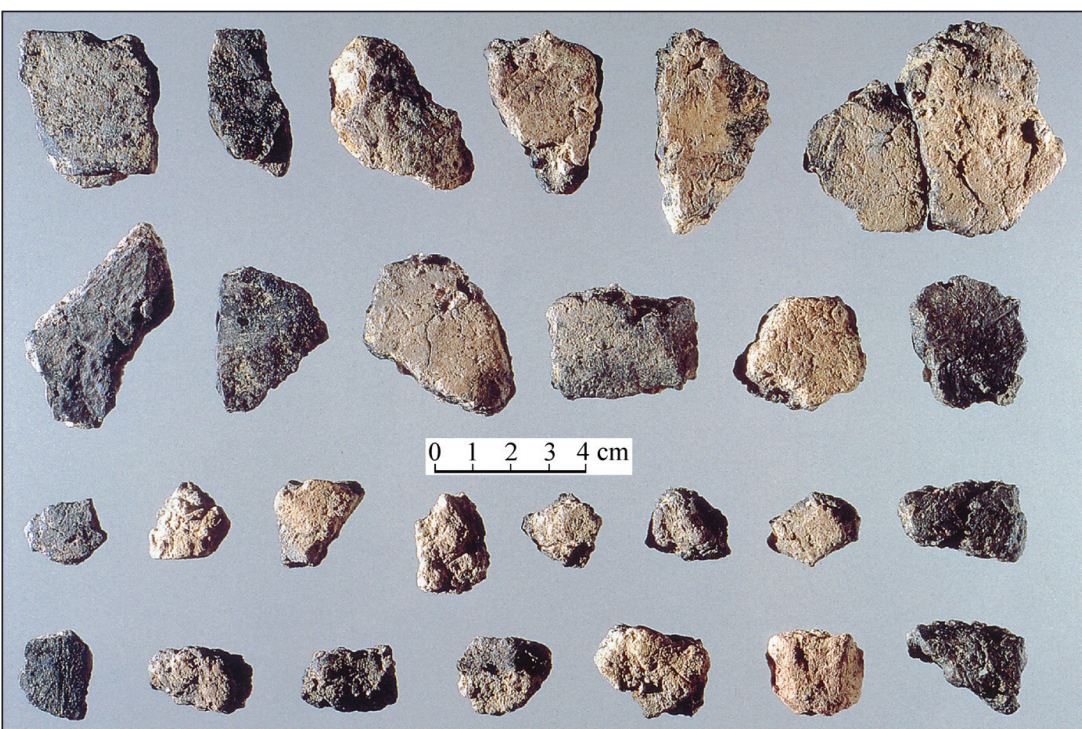

Fig. 3. Potsherds from the Odai Yamamoto 1 site, dated to c. 1350013800 BP (after Odai Yamamato 1999; modified).
calBP (Tab. 1), centred at 18010 calBP, represent the oldest case of pottery-making in greater East Asia (Fig. 2). The most reliable age for pottery from the Xianrendong Cave, in my opinion, is $c .14600$ calBP. For other sites in South China such as Miaoyan Cave and Wang Dong Cave [Diaotonghuan] (Fig. 1), the age of the earliest potsherd-containing strata is not older than $c .16600$ calBP (Tab. 1).

\section{Japanese Islands}

Since the publication of summary works in the early 2000s (Ono et al. 2002; Keally et al. 2003; 2004),

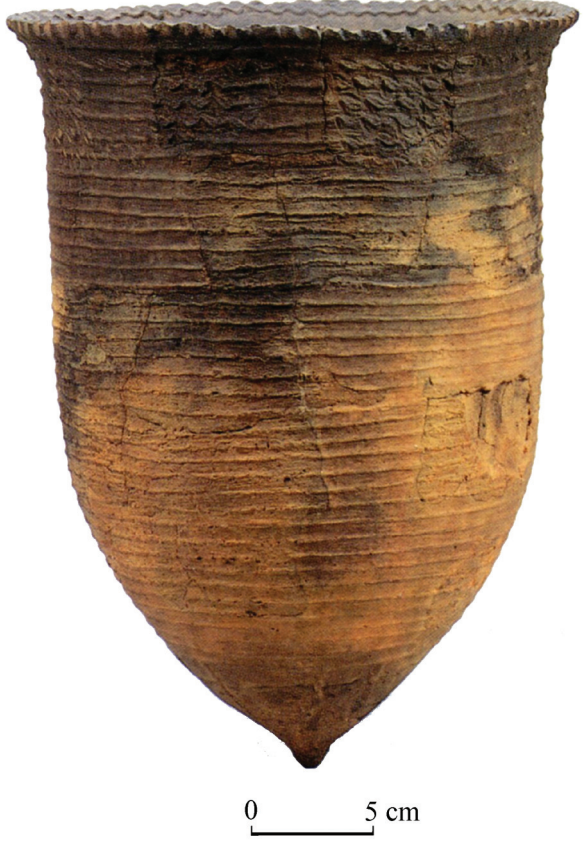

Fig. 4. Pottery from the Omotedate site, Incipient Jomon (after Jomon 1996b; modified). supplemented by more recent overviews (Omoto et al. 2010; Kuzmin 2013a), the situation with the earliest pottery corresponding to the Incipient Jomon of Japan has been consistent. The oldest ${ }^{14} \mathrm{C}$ dates, c. 13 500-13800 BP (centred at c. 17000 calBP), come from the northern part of Honshu Island at the Odai Yamamoto 1 site (Fig. 1, Tab. 1). Potsherds found at this site are quite fragmentary (Fig. 3), and it is not possible to reconstruct the vessel's shape. Pottery from other sites is represented mainly by pointed-bottomed vessels (Figs. 4-6), but round-bottomed pots (Fig. 7) and flat-bottomed ones

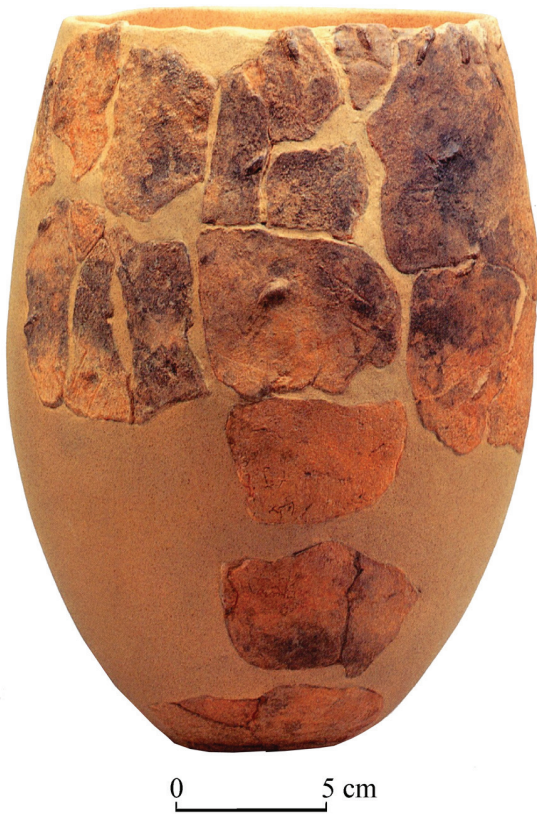

Fig. 5. Pottery from the Senpukuji Cave (bean-relief design) dated to c. 12200 BP (after Jomon 1996b; modified). 


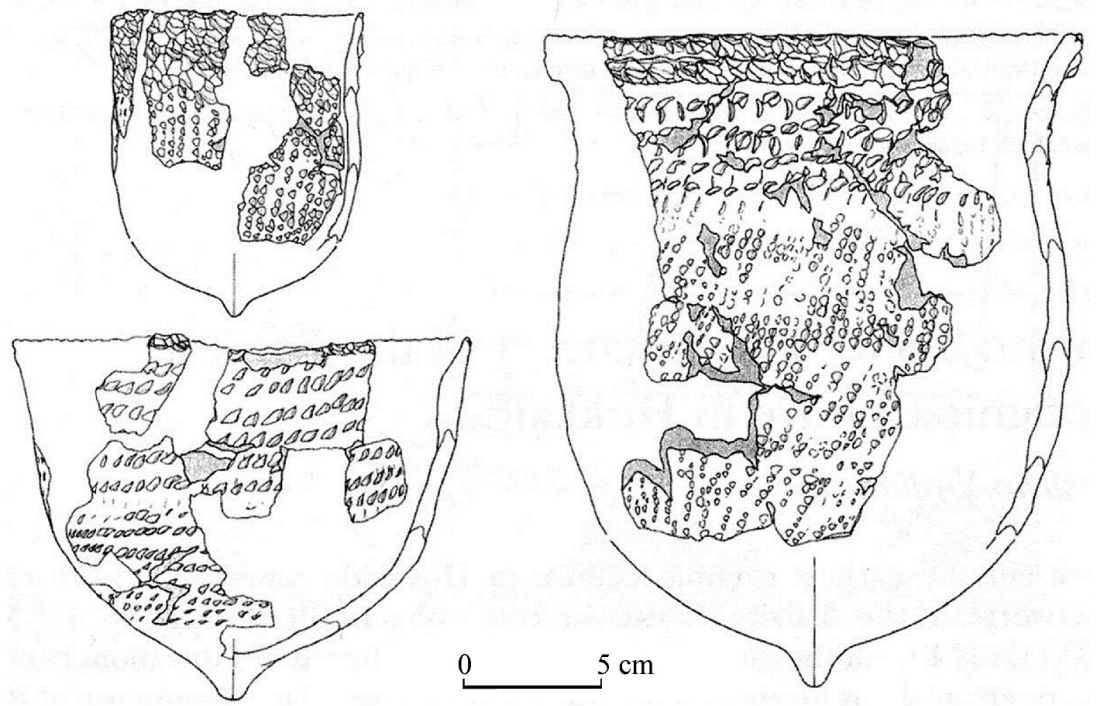

Fig. 6. Pottery from the Taisho 3 site dated to c. 12460 BP (after Yamahara 2006; modified).

(e.g., Keally et al. 2003.4) are also known. The recent study of lipids in Incipient Jomon pottery indicated that it was used for cooking (Craig et al. 2013); therefore, the function of the earliest ceramics in Japan was utilitarian.

Based on current knowledge, the existence of pottery on the Japanese Islands can be securely established from c. 17000 calBP onwards (Fig. 2, Tab. 1).

\section{The Russian Far East}

Since analysis of the main results related to ${ }^{14} \mathrm{C}$ dating of the earliest sites in the Amur River basin (Kuz$\min 2006 ; 2013 a$ ), the situation has not changed. It is now widely accepted that the first evidence of pottery-making in this region dates to $c .12380-$ $13260 \mathrm{BP}$, corresponding to $c$. $14110-16240$ calBP (Fig. 2, Tab. 1). Flat-bottomed vessels were reconstructed at the Gasya and Goncharka 1 sites (Figs. 89). The most probable function of this pottery was utilitarian (e.g., Medvedev 1995; Kuzmin 2013a).

The issue of the pottery from the Gromatukha site in the middle course of the Amur River can now be clarified in the light of new research conducted by Igor Y. Shewkomud and Oksana Yanshina (2012). Previously, Mikaeil Kani (1992) had reconstructed the vessel as round-bottomed (Figs. 10, 11). According to Shewkomud and Yanshina (2012), the most common shape of pottery at the lower level of the Gromatukha site, dated to $c$. 12380 BP (or 1411014850 calBP), is flat-bottomed (Fig. 12).

Why are these reconstructions so different? This question puzzled me for a long time, until I saw the conclusion by Shewkomud and Yanshina (2012). After that, I examined the circumstances related to the acquisition of Kani's (1992) material. The eyewitness for this is $\mathrm{Ku}-$ mi Kato (1992), who participated in the trip when these potsherds were obtained. During the field excursion in 1988 (not in 1991, as Shevkomud and Yanshina (2012. 220) assumed), Japanese archaeologists along with Russian colleagues conducted a very brief (four hours only) survey of the Gromatukha site (Kato 1992.117). Therefore, it seems less likely that the small Russian-Japanese team was able to dig a proper test pit, as suggested by Shevkomud and Yanshina (2012.220). More probably, the potsherds were collected from the talus where the cultural material from all components of the Gromatukha site has accumulated since the large-scale excavations in the 1960s (Okladnikov, Derevianko 1977). Because it is now clear that the Gromatukha site contains material of the later Neolithic along with the Initial Neolithic of the Gromatukha complex, it is quite possible that the reconstructed vessel belongs to the Belkachi complex dated to $c$. 3900-6300 BP (e.g., Mochanov, Fedoseeva 1985; Alekseev, Dyakonov 2009) with round-bottomed and cord-decorated pottery.

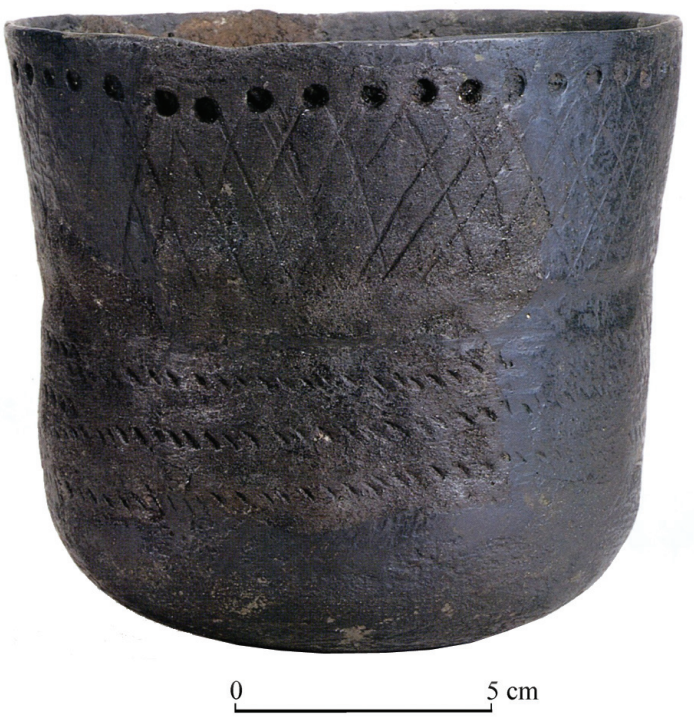

Fig. 7. Pottery from the Torihama site dated to $\mathrm{c}$. 11800 BP (after Jomon 1996b; modified). 
Shevkomud and Yanshina (2012.221) noted the single round-bottom fragment recovered from the entire collection of the 1960s excavations at the Gromatukha site, which consists of several hundred potsherds. It might be that this particular piece is not related to the Initial Neolithic complex, because the prevailing paradigm of Aleksei P. Okladnikov and Anatolii P. Derevianko (1977) was a gradual development of the Neolithic in the middle course of the Amur River basin, and all the potsherds were described as belonging to the single cultural complex. Therefore, the reconstruction of round-bottomed pottery of the Initial Neolithic at the Gromatukha site (e.g., Kani 1992; Jomon 1996a; 1996b) is most probably unreliable. Perhaps, the notion that pottery emerged on the Japanese Islands, which was common in the 1970s and 1980s (e.g., Aikens 1995), influenced the reconstruction of the Gromatukha vessel, because Kani (1992) assumed that its origin was directly related to the spread of pottery-making from Japan to the neighbouring regions.

\section{Transbaikal}

Since the early 2000s, new data on the earliest pottery in the Transbaikal region of Eastern Siberia have been obtained. The Ust-Karenga 12 site is located in the northern part of this territory, on the Vitim Plateau, which is covered by dense forest consisting mainly of Dahurian larch (Suslov 1961.293-294), on the border between the middle and southern taiga zones (Tishkov 2002.219). Another cluster of sites, Studenoe 1, Ust-Menza 1, and Ust-Kyakhta, is

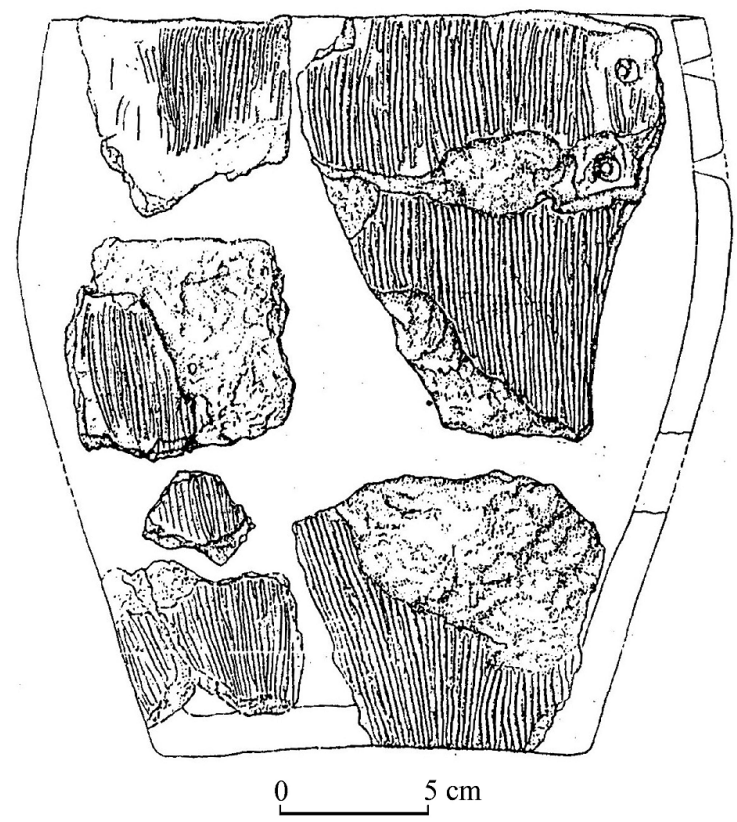

Fig. 8. Pottery from the Gasya site dated to c. 12960 BP (after Derevianko, Medvedev 1995; modified).

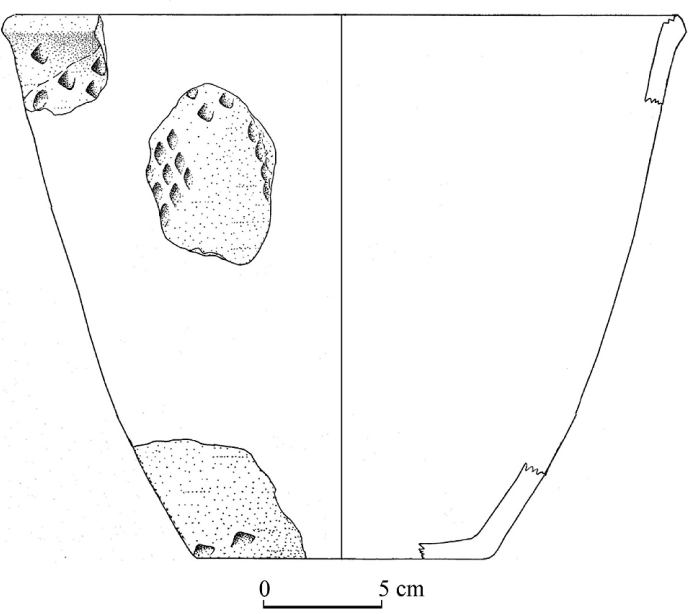

Fig. 9. Pottery from the Goncharka site dated to c. 12500 BP (after Shewkomud, Yanshina 2012; modified).

situated in the southern part of the Transbaikal, in the southern taiga zone (Tishkov 2002.219). The most important of these are Studenoe 1 and UstMenza 1 in the Khilok-Chikoy region (Suslov 1961. 292-293) or Dahuria (Shahgedanova et al. 2002. 335 ), with mountain ranges and river valleys covered by conifer forests (spruce, fir, and Siberian pine) (Suslov 1961.320).

In the northern Transbaikal, the age of dispersed charcoal collected from Layer 7 with pottery at the Ust-Karenga 12 site is $c .12180 \mathrm{BP}$ (13 840-14 240 calBP (Tab. 1) (see Kuzmin, Vetrov 2007). It was proposed that the most secure estimate is the age of charcoal from a hearth in Layer 7, c. $11240 \mathrm{BP}$ (12 930-13280 calBP) (see Tab. 1).

As for the southern region, I previously suggested that the earliest pottery from Layer 8 of Studenoe 1 (also known as Studenoe 1/1) site could be as old as c. 12000 BP (13 470-14 210 calBP) (Kuzmin 2013. 547-548). Recently, new data were generated by Irina N. Razgildeeva et al. (2013). Food adhesions attached to the potsherds from Layer 9G (the lowermost stratum with pottery at this site) were ${ }^{14} \mathrm{C}$ dated to $c$. $11600-11960 \mathrm{BP}$; the oldest value corresponds to $13580-14020$ calBP (see Tab. 1). Several ${ }^{14} \mathrm{C}$ dates of $c .11570-11730 \mathrm{BP}$ were obtained from food residues on pottery in Layer 8 , with the oldest calendar age being 13 450-13720 calBP (Tab. 1). These new ${ }^{14} \mathrm{C}$ values are in accord with the charcoal date from Layer 8 at $c .11995$ BP (1347014210 calBP; see Tab. 1).

Pottery from Layer 9G of the Studenoe 1 site is parabolic in shape (Fig. 13.A), with walls $0.6-0.7 \mathrm{~cm}$ thick 


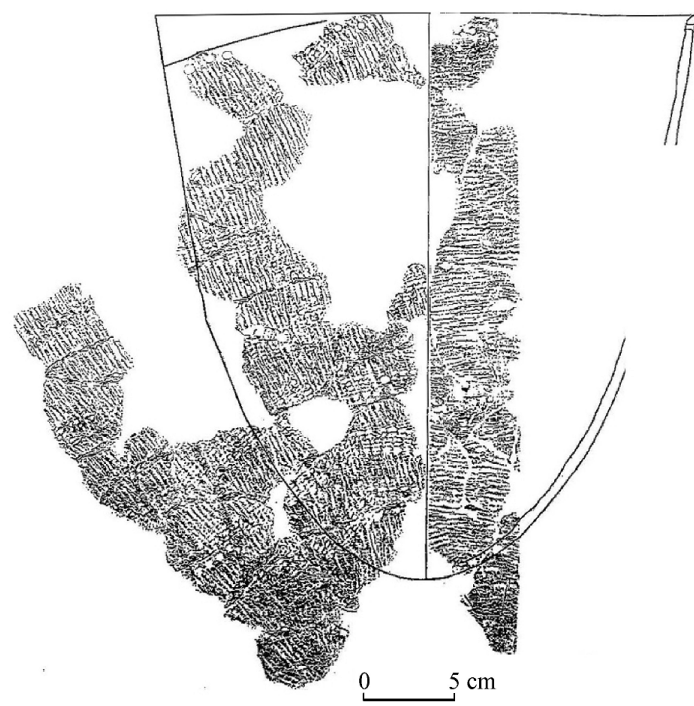

Fig. 10. Reconstruction of pottery from the Gromatukha site (after Kani 1992; modified).

at the rim, and $1.0-1.1 \mathrm{~cm}$ at the bottom. The clay paste contains plant material added at the time of manufacture. The diameter of the vessel at the rim is $23-32 \mathrm{~cm}$, and $17 \mathrm{~cm}$ at the bottom. On the surface, grooves made by a tool with 8-10 protruding 'teeth' and vertical traces made by cord (perhaps, rope on a stick) are visible. The pottery from Layer 8 (Fig. 13.B) is similar to that from Layer 9G; however, no bottom parts were found (Razgildeeva et al. 2013.175).

Razgildeeva et al. (2013) concluded that the ${ }^{14} \mathrm{C}$ age for food adhesions at the Studenoe 1 site is older than the ${ }^{14} \mathrm{C}$ values obtained on charcoal, and the former should be $c$. 12 000-13 000 calBP. Perhaps, they are not aware of the charcoal ${ }^{14} \mathrm{C}$ date of $c$. 11995 BP (Buvit et al. 2003) corresponding to 13 470-14 210 calBP. This value fits perfectly well with the age of the food remains, and in my opinion, the pottery from the Studenoe 1 site can now be securely dated to $c .12000 \mathrm{BP}$ (centred at $c .13840$ calBP).

The earliest pottery from the Ust-Menza 1 site was recently ${ }^{14} \mathrm{C}$ dated for the first time (Razgildeeva et al. 2013). Previously, it was associated with the Early Holocene, c. 8715 BP (e.g., Kuzmin, Orlova 2000 ). The age of food adhesion on pottery from Layer 8 is $c$. $11500 \mathrm{BP}$ (13 280-13 470 calBP; Tab. 1). Potsherds are quite fragmentary, but their overall appearance is similar to the pottery from the Studenoe 1 site (Razgildeeva et al. 2013.176). The ${ }^{14} \mathrm{C}$ date on food residue is considered older than its real age judging from the ${ }^{14} \mathrm{C}$ value of $c .10380 \mathrm{BP}$ (11 350-12 710 calBP) in the underlying Layer 11

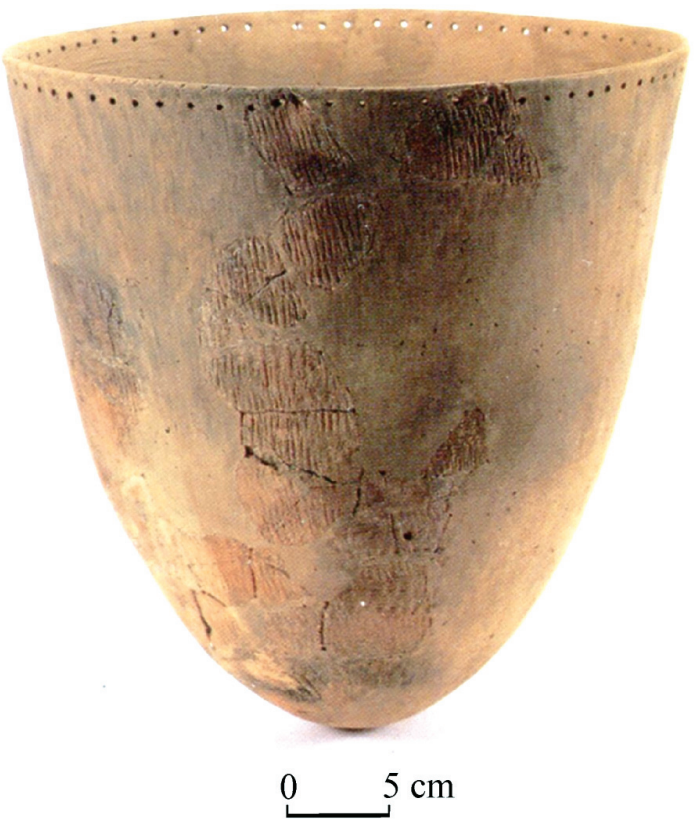

Fig. 11. Reconstruction of pottery from the Gromatukha site (after Jomon 1996a; modified).

(see Razgildeeva et al. 2013.172), and the 'true' age of the pottery from Ust-Menza 1 was suggested as c. 12 000-13000 calBP (Razgildeeva et al. 2013). In my opinion, the ${ }^{14} \mathrm{C}$ dating of adhesions is quite reliable, as in the case of the Studenoe 1 site (see above), and the age of pottery from Layer 8 at the Ust-Menza site can be accepted as $c .13380$ calBP.

Based on the general appearance of pottery from the entire Transbaikal region (including the Ust-Karenga 12 , Studenoe 1, Ust-Menza 1 , and Ust-Kyakhta

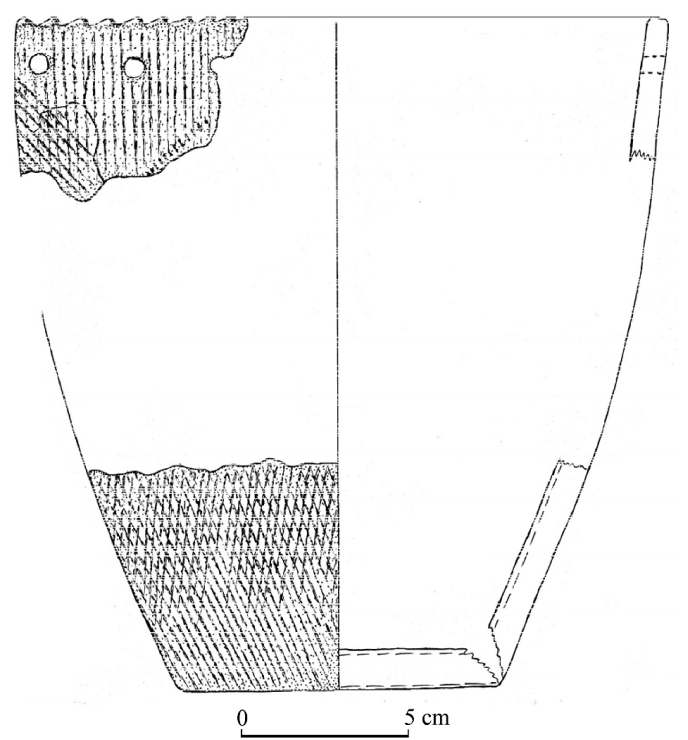

Fig. 12. Pottery from the Gromatukha site dated to c. 12380 BP (after Shewkomud, Yanshina 2012; modified). 


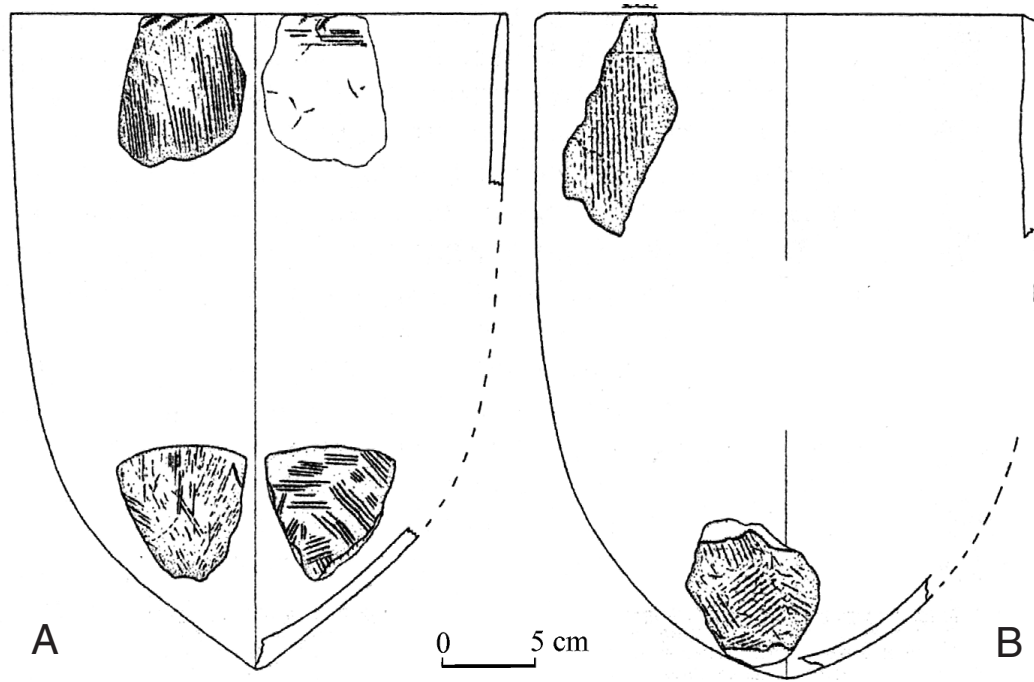

Fig. 13. Pottery from the Studenoe 1 site: A - from Layer 9G (dated to c. 11960-11 600 BP); B -from Layer 8 (dated to c. $11730-11570$ BP) (after Razgildeeva et al. 2013; modified).

sites, see Fig. 1), it was concluded that it represents a single cultural tradition of the earliest pottery-making in Eastern Siberia (Razgildeeva et al. 2013.177). Its age can now be established as $c .12000 \mathrm{BP}(c$. 14000 calBP) (Fig. 2).

\section{Centre(s) of pottery origin(s) in East Asia and neighbouring regions - how many?}

Based on previous data, three primary centres of pottery origin in greater East Asia have been suggested: (1) South China; (2) the Japanese Islands; and (3) the Russian Far East (Amur River basin) (e.g., Kuz$\min 2010 ; 2013 a$ ). This model is still valid, especially in the light of updated information on the age of the earliest pottery complexes outside of these centres (Fig. 14). For example, the oldest pottery in Korea (between the far eastern Russian and Japanese centres) is dated to $c .11780$ calBP at the Kosanni site, and $c .7960$ calBP at the Osanni site (Bae, Kim 2003; Choe, Bale 2002). The earliest pottery complexes situated between the southern Chinese centre and the Japanese Islands, the Russian Far East, and the Transbaikal date to $c$. 11900 calBP in North China at the Nanzhuangtou site (see Tab. 1), c. 10360 BP in Central China at the Lijiagou site (Wang et al. 2015), and c. 8480 calBP in Mongolia (e.g., Kuzmin vison et al. (2006).
2014.720). Therefore, to the best of my knowledge, no reliable evidence about the diffusion/dispersal of potterymaking from any of these three centres to the neighbouring regions in greater East Asia (including Siberia) is known, contrary to the conclusion that "Evidence for the dispersal of hunter-gatherer pottery from East Asia and via Siberia, across the continent to Europe suggests that it played an important role in the wider development of Eurasian pottery" (Gibbs, Jordan 2013.28).

As for the Transbaikal, today we have much stronger evidence in favour of a very early appearance of pottery in this region - at $c .14000$ calBP, most probably independent of the primary East Asian centres (Fig. 14). However, it did not influence the more western parts of Siberia in terms of the spread of pottery-making. This issue was recently analysed by Kuzmin (2014), and no solid evidence was found concerning the diffusion/dispersal of pottery-making from East Asia toward Eastern Europe via Siberia sensu Dolukhanov and Shukurov (2004) and Da-

Kevin Gibbs (2015.340) stated: "It is possible that in some regions the invention of pottery correspond-

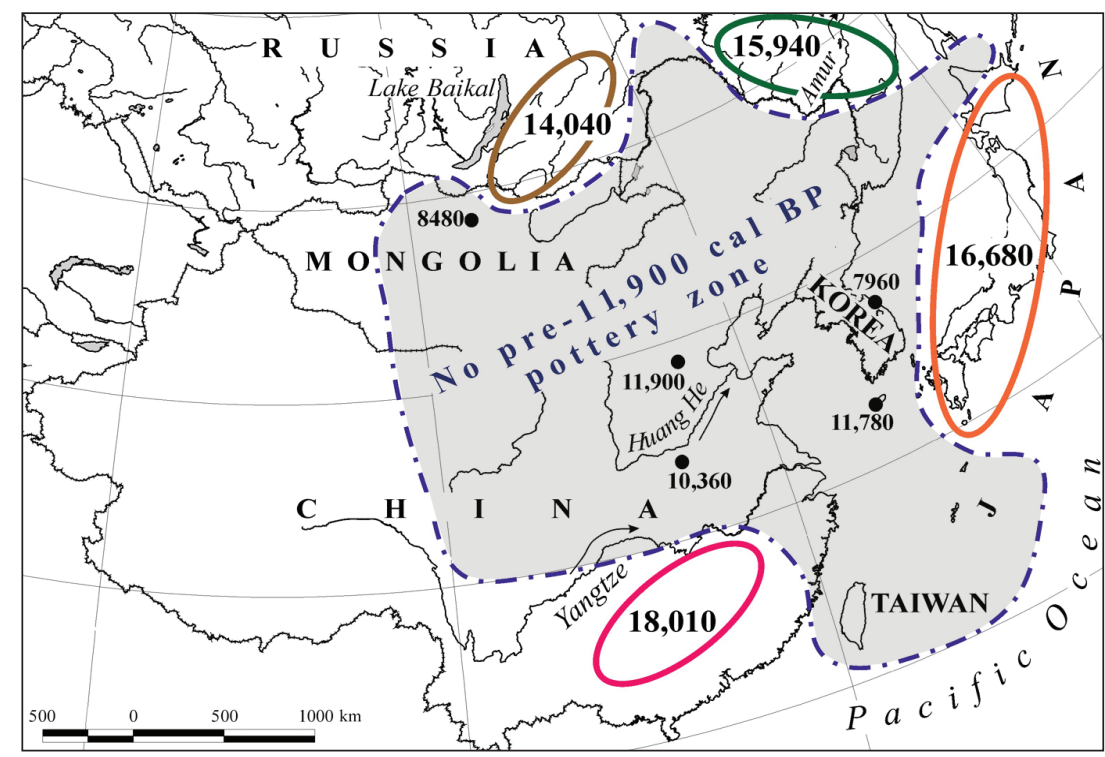

Fig. 14. Primary centres of pottery origin in greater East Asia and neighbouring regions with their calibrated ages (the mid-2015 state-of-the-art). 
ed with a newly developed need, perhaps the introduction of a new potential food source that could be better exploited using durable, water-tight containers." I drew the following conclusion some time ago: "The appearance of pottery was most probably facilitated by the necessity for East Asian populations in the Late Glacial (after c. 16,000 BP, or c. 19,000 cal. BP) to have light, easily made containers for the processing and storing of such types of food as wild plants and their nuts and fruit, which are otherwise hard to utilize without vessels for boiling and leaching" (Kuzmin 2013a. 551). A similar view was expressed in the 1970 s (e.g., Ikawa-Smith 1976.515).

\section{Conclusions}

Three regions in greater East Asia, namely South China, the Japanese Islands, and the Russian Far East, are the primary centres of pottery origin in the old World. It is most likely that pottery-making emerged in these independently of each other, as recent archaeological and chronological data have suggested. It is worthwhile to emphasise that the earliest evidence of pottery preceded the climatic amelioration in the Late Glacial period, the Bølling - Allerød warm interval (c. 14700-12900 calBP) (Fig. 2).
In Siberia, the oldest pottery is now known from the Transbaikal, with a secure age of $c .14000$ calBP. It is, however, very unlikely that it is related to the later pottery complexes in both the eastern and western parts of Siberia. It seems that pottery-making in Siberia, as in East Asia in general, emerged in several regions independently and almost simultaneously.

\section{ACKNOWLEDGEMENTS}

I am grateful to Prof. Mihael Budja for the invitation to participate in this volume, and to Prof. Akira Ono (Meiji University, Tokyo, Japan) for providing information about some Japanese sites. Dr. Susan Keates kindly checked the grammar of the manuscript, and I am indebted for that. This research was supported by the Japan Society for Promotion of Science (2015); the Russian Foundation for Basic Sciences (RFFI), grant No. 12-06-00045; the Fulbright Program (USA), grant No. 03-27672; the Japan Foundation; the Korea Foundation; the Civil Research and Development Foundation (USA), grant No. RUG1-7097-NO-13; and the Ministry of Education, Science, Culture and Sport (Mombu Kagakusho) (Japan). This study was also supported by a grant from Tomsk State University 'D. I. Mendeleev Academic Fund' Programme (grant No. 8.1.22.2015) in 2014-2015.

\section{$\therefore$}

\section{References}

Aikens C. M. 1995. First in the world: the Jomon pottery of early Japan. In W. K. Barnett, J. W. Hoopes (eds.), The Emergence of Pottery: Technology and Innovation in Ancient Societies. Smithsonian Institution Press. Washington, D.C. \& London: 11-21.

Alekseyev A. N., Dyakonov V. M. 2009. Radiocarbon chronology of Neolithic and Bronze Age cultures in Yakutia. Archaeology, Ethnology \& Anthropology of Eurasia 37 (3): 26-40.

Bae K., Kim J.-C. 2003. Radiocarbon chronology of the Palaeolithic complexes and the transition to the Neolithic in Korea. The Review of Archaeology 24(2): 46-49.

Boaretto E., Wu X., Yuan J., Bar-Yosef O., Chu V., Pan Y., Liu K., Cohen D., Jiao T., Li S., Gu H., Goldberg P. and Weiner S. 2009. Radiocarbon dating of charcoal and bone collagen associated with early pottery at Yuchanyan Cave, Hunan Province, China. Proceedings of the National Academy of Sciences of the United States of America 106: 9595-9600.
Buvit I., Waters M. R., Konstantinov M. V. and Konstantinov A. V. 2003. Geoarchaeological investigations at Studenoe, an Upper Paleolithic site in the Transbaikal region, Russia. Geoarchaeology 18: 649-673.

Choe C. P., Bale M. T. 2002. Current perspectives on settlement, subsistence, and cultivation in prehistoric Korea. Arctic Anthropology 39: 95-121.

Cohen D. J. 2013. The advent and spread of early pottery in East Asia: new dates and new considerations for the world's earliest ceramic vessels. Journal of Austronesian Studies 4: 55-92.

Craig O. E., Saul H., Lucquin A., Nishida Y., Taché K., Clarke L., Thomson A., Altoft D. T., Uchiyama J., Ajimoto M., Gibbs K., Isaksson S., Heron C. P. and Jordan P. 2013. Earliest evidence for the use of pottery. Nature 496: 351-354.

Davison K., Dolukhanov P., Sarson G. R. and Shukurov A. 2006. The role of waterways in the spread of the Neolithic. Journal of Archaeological Science 33: 641-652. 
Derevianko A. P., Medvedev V. E. 1995. The Amur River basin as one of the earliest centers of ceramics in the Far East. In H. Kajiwara (ed.), The Origin of Ceramics in East Asia and the Far East. Tohoku Fukushi University Press. Sendai: 13-25.

Dolukhanov P., Shukurov A. 2004. Modelling the Neolithic dispersal in northern Eurasia. Documenta Praehistorica 31: 35-47.

Dikshit K. N., Hazarika M. 2012. The earliest pottery in East Asia: a review. Purātattva 42: 227-237.

Gibbs K. 2015. Pottery invention and innovation in East Asia and the Near East. Cambridge Archaeological Journal 25: 339-351.

Gibbs K., Jordan P. 2013. Bridging the boreal forest: Siberian archaeology and the emergence of pottery among prehistoric hunter-gatherers of northern Eurasia. Sibirica 12: $1-38$.

Ikawa-Smith F. 1976. On ceramic technology in East Asia. Current Anthropology 17: 513-515.

Jomon 1996a.Jomon Jidai Sosoki (The Incipient Jomon of Japan). Exhibition Booklet. Yokohama Rekishi Hakubutsukan. Yokohama. (in Japanese)

Jomon Jidai Sosoki (The Incipient Jomon of Japan). Exhibition Catalogue. Yokohama Rekishi Hakubutsukan. Yokohama. (in Japanese)

Jordan P., Zvelebil M. (eds.) 2009. Ceramics before Farming: The Dispersal of Pottery among Prehistoric Eurasian Hunter-Gatherers. Left Coast Press. Walnut Creek, CA.

Kani M. 1992. Fukugen sareta Shiberia no Jomon semon no doki Amurugawa ryuiki Guromathuha iseki shutsudo (Reconstructed Siberian cord-marked pottery from the Gromatukha site). Kikan Kokogaku 38: 66-67. (in Japanese)

Kato K. 1992. Sibir v Serdtse Yapontsa (Siberia in the Heart of a Japanese Man). Nauka Publ. Novosibirsk. (in Russian)

Keally C. T., Taniguchi Y. and Kuzmin Y. V. 2003. Understanding the beginnings of pottery technology in Japan and neighboring East Asia. The Review of Archaeology 24(2): 3-14.

Keally C. T., Taniguchi Y., Kuzmin Y. V. and Shewkomud I. Y. 2004. Chronology of the beginning of pottery manufacture in East Asia. Radiocarbon 46: 345-351.

Kuzmin Y. V. 2006. Chronology of the earliest pottery in East Asia: progress and pitfalls. Antiquity 80: 362-371.
2010. The origin of pottery in East Asia and its relationship to environmental changes in the Late Glacial. $R a$ diocarbon 52: 415-420.

2013a. Origin of Old World pottery as viewed from the early 2010s: when, where and why? World Archaeology 45: 539-556.

2013b. Two trajectories in the Neolithization of Eurasia: pottery versus agriculture (spatiotemporal patterns). Radiocarbon 55: 1304-1313.

2014. The Neolithization of Siberia and the Russian Far East: major spatiotemporal trends (the 2013 state of the art). Radiocarbon 56: 717-722.

Kuzmin Y. V., Jull A. J. T., Lapshina Z. S. and Medvedev V. E. 1997. Radiocarbon AMS dating of the ancient sites with earliest pottery from the Russian Far East. Nuclear Instruments and Methods in Physics Research B 123: 496-497.

Kuzmin Y. V., Orlova L. A. 2000. The Neolithization of Siberia and the Russian Far East: radiocarbon evidence. $A n$ tiquity 74: 356-365.

Kuzmin Y. V., Vetrov V. M. 2007. The earliest Neolithic complex in Siberia: the Ust-Karenga 12 site and its significance for the Neolithisation process in Eurasia. Documenta Praehistorica 34: 9-20.

MacNeish R. S. 1999. A Paleolithic-Neolithic sequence from South China Jiangxi Province, PRC. In K. Omoto (ed.), Interdisciplinary Perspectives on the Origins of the Japanese. International Research Center for Japanese Studies. Kyoto: 233-255.

McKenzie H. G. 2009. Review of early hunter-gatherer pottery in Eastern Siberia. In P. Jordan, M. Zvelebil (eds.), Ceramics before Farming: The Dispersal of Pottery among Prehistoric Eurasian Hunter-Gatherers. Left Coast Press. Walnut Creek, CA: 167-208.

Medvedev V. E. 1995. To the problem of the Initial and Early Neolithic of the Lower Amur. In A. P. Derevianko, V. E. Larichev (eds.), Obozrenie Rezultatov Polevykh $i$ Laboratornykh Issledovaniy Arkheologov, Etnografov $i$ Antropologov Sibiri i Dalnego Vostoka v 1993 Godu. Institut Arkheologii i Etnografii. Novosibirsk: 228-237.

Mochanov Y. A., Fedoseeva S. A. 1985. Main periods in the ancient history of Northeast Asia. In V. L. Kontrimavichus (ed.), Beringia in the Cenozoic Era. A. A. Balkema. Rotterdam: 669-693.

Nakamura T., Taniguchi Y., Tsuji S. and Oda H. 2001. Radiocarbon dating of charred residues on the earliest pottery. Radiocarbon 43: 1129-1138. 
Nesterov S. P., Sakamoto M., Imamura M. and Kuzmin Y. V. 2006. The Late-Glacial Neolithic complex of the Gromatukha site, Russian Far East: new results and interpretations. Current Research in the Pleistocene 23: 46-49.

Odai Yamamoto 1999. Odai Yamamoto I Iseki no Kokogaku Chosa (Archaeological Research at the Odai Yamamoto I Site). Department of Archaeology. Kokugakuin University. Tokyo. (in Japanese)

Okladnikov A. P., Derevianko A. P. 1977. Gromatukhinskaya Kultura (The Gromatukha Culture). Nauka Publ. Novosibirsk. (in Russian)

Okladnikov A. P., Medvedev V. E. 1983. Raskopki mnogosloinogo poseleniya Gasya na Nizhnem Amure (The excavations in the multilayered site of Gasya on the Lower Amur River basin). Izvestiya Sibirskogo Otdeleniya Akademii Nauk SSSR 20(1): 93-97. (in Russian)

Omoto K., Takeishi K., Nishida S. and Fukui J. 2010. Calibrated ${ }^{14} \mathrm{C}$ ages of Jomon sites, NE Japan, and their significance. Radiocarbon 52: 534-548.

Ono A., Sato H., Tsutsumi T. and Kudo Y. 2002. Radiocarbon dates and archaeology of the Late Pleistocene in the Japanese Islands. Radiocarbon 44: 477-494.

Razgildeeva I. I., Kunikita D. and Yanshina O. V. 2013. New data about age of oldest pottery complexes of west Transbaikal area. In G. I. Medvedev (ed.), Eurasia in the Cenozoic. Stratigraphy, Paleoecology, Cultures. Issue 2. Fundamental Problems of Formation and Paleoenvironment Diversity in Eurasia. Paradigm Shift. Irkutsk State University Press. Irkutsk: 168-178.

Reimer P. J. and 30 co-authors. 2013. IntCal13 and Marine 13 radiocarbon age calibration curves $0-50,000$ years cal BP. Radiocarbon 55: 1869-1887.

Sato H., Izuho M. and Morisaki K. 2011. Human cultures and environmental changes in the Pleistocene-Holocene transition in the Japanese Archipelago. Quaternary International 237: 93-102.

Shahgedanova M., Mikhailov N., Larin S. and Bredikhin A. 2002. The mountains of southern Siberia. In M. Shahgedanova (ed.), The Physical Geography of Northern Eurasia. Oxford University Press. Oxford - New York: 314-349.
Shevkomud I. Y. 1997. New research concerning the 0sipovskaya culture in the Amur River basin. Kokogaku Kenkyu 44: 102-109.

Shevkomud I. Y., Yanshina 0. V. 2012. Beginning of the Neolithic in the Amur River Basin: The Goncharka-1 Site. Museum of Archaeology and Ethnography. St. Petersburg.

Silva F., Steele J., Gibbs K. and Jordan P. 2014. Modeling spatial innovation diffusion from radiocarbon dates and regression residuals: the case of early old World pottery. Radiocarbon 56: 723-732.

Suslov S. P. 1961. Physical Geography of Asiatic Russia. W. H. Freeman. San Francisco \& London.

Tishkov A. 2002. Boreal forests. In M. Shahgedanova (ed.), The Physical Geography of Northern Eurasia. Oxford University Press. New York: 217-233.

Wang Y. J., Cheng H., Edwards R. L., An Z. S., Wu J. Y., Shen C.-C. and Dorale J. A. 2001. A high-resolution absolutedated Late Pleistocene monsoon record from Hulu Cave, China. Science 294: 2345-2348.

Wang J., Zhang S., Gu W., Wang S., He J., Wu X., Qu T., Zhao J., Chen Y. and Bar-Yosef 0. 2015. Lijiagou and the earliest pottery in Henan Province, China. Antiquity 89: 273-291.

Wu X., Zhang C., Goldberg P., Cohen D., Pan Y., Arpin T. and Bar-Yosef 0. 2012. Early pottery at 20,000 years ago in Xianrendong Cave, China. Science 336: 1696-1700.

Yamahara T. 2006. Taisho 3 site: the discovery of the earliest ceramic culture in Hokkaido. Current Research in the Pleistocene 23: 35-36.

Yuan S., Chen T. and Zhou K. 1992. Nanzhuangtou yizhi tan shisi niandai ceding yu wenhuaceng baofen fenxi $(14 \mathrm{C}$ dating and pollen analysis of the cultural layer at the Nanzhuangtou site). Kaogu 11: 967-970. (in Chinese)

Yuan S., Zhou G., Guo Z., Zhang Z., Gao S., Li K., Wang J., Liu K., Li B. and Lu X. 1995. 14C AMS dating the transition from the Paleolithic to the Neolithic in South China. Radiocarbon 37: 245-249. 
